\title{
Varying type of forage, concentration of metabolizable protein, and source of carbohydrate affects nutrient digestibility and production by dairy cows
}

\author{
W. P. Weiss ${ }^{* 1}$ N. R. St-Pierre, $†$ and L. B. Willett ${ }^{*}$ \\ *Department of Animal Sciences, Ohio Agricultural Research and Development Center, The Ohio State University, Wooster 44691 \\ †Department of Animal Sciences, Ohio Agricultural Research and Development Center, The Ohio State University, Columbus 43210
}

\begin{abstract}
The effects of forage source, concentration of metabolizable protein (MP), type of carbohydrate, and their interactions on nutrient digestibility and production were evaluated using a central composite treatment design. All diets (dry basis) contained 50\% forage that ranged from 25:75 to 75:25 alfalfa silage:corn silage. Rumen-degradable protein comprised $10.7 \%$ of the dry matter (DM) in all diets, but undegradable protein ranged from 4.1 to $7.1 \%$, resulting in dietary MP concentrations of 8.8 to $12.0 \%$ of the DM. Dietary starch ranged from 22 to $30 \%$ of the DM with a concomitant decrease in neutral detergent fiber concentrations. A total of 15 diets were fed to 36 Holstein cows grouped in 6 blocks. Each block consisted of three 21-d periods, and each cow was assigned a unique sequence of 3 diets, resulting in 108 observations. Milk production and composition, feed intake, and digestibility of major nutrients (via total collection of feces and urine) were measured. Few significant interactions between main effects were observed. Starch concentration had only minor effects on digestibility and production. Replacing corn silage with alfalfa decreased digestibility of $\mathrm{N}$ but increased digestibility of neutral detergent fiber. Increasing the concentration of MP increased $\mathrm{N}$ digestibility. The concentration (Mcal $/ \mathrm{kg}$ ) of dietary digestible energy (DE) increased linearly as starch concentration increased (very small effect) and was affected by a forage by MP interaction. At low MP, high alfalfa reduced DE concentration, but at high $\mathrm{MP}$, increasing alfalfa increased DE concentration. Increasing alfalfa increased DM and DE intakes, which increased yields of energy-corrected milk, protein, and fat. Increasing MP increased yields of energy-corrected milk and protein. The response in milk protein to changes in MP was much less than predicted using the National Research Council (2001) model.
\end{abstract}

Key words: digestibility, starch, alfalfa, protein

Received March 26, 2009.

Accepted August 3, 2009.

${ }^{1}$ Corresponding author: weiss.6@osu.edu

\section{INTRODUCTION}

The nutrient and ingredient composition of diets fed to dairy cows affects nutrient digestibility, the quantity and composition of manure, and the yield and composition of milk. Excretion of manure $\mathrm{N}$ is of particular importance for environmental and human health reasons (NRC, 2002) and because protein is an expensive nutrient. The amount of $\mathrm{N}$ excreted by a cow is positively correlated with the concentration of dietary CP (Yan et al., 2006), whereas the route of excretion (urinary or fecal) depends on the quantity and type of $\mathrm{N}$ consumed (Nennich et al., 2006). Corn silage and alfalfa silage are the predominant forages fed in many areas of the United States, and because they differ greatly in CP concentration, source of dietary CP differs as type of silage changes. Replacing alfalfa silage with corn silage and soybean meal often increases urinary $\mathrm{N}$ and decreases fecal N outputs (Wattiaux and Karg, 2004b). Replacing NDF with starch can reduce excretion of total $\mathrm{N}$ (when $\mathrm{N}$ intake is constant) and can change the route of excretion (Castillo et al., 2001). Interactions between amount of $\mathrm{N}$ consumed, type of forage, and type of carbohydrate are likely. For example, replacing NDF with starch can increase the digestible energy (DE) concentration of a diet, which can increase milk protein synthesis (Beckman and Weiss, 2005), but this would only occur if adequate MP is available. High starch with adequate MP might reduce excretion of $\mathrm{N}$ via manure, whereas high starch with low MP should not.

The primary objective of this experiment was to determine dietary effects on excretion of $\mathrm{N}$ and on the evolution of ammonia from manure. However, reducing the excretion of $\mathrm{N}$ (or reducing the amount of ammonia produced from manure) by a cow does not necessarily reduce the environmental impact of the dairy industry. Indeed, if increasing $\mathrm{N}$ efficiency ( $\mathrm{N}$ secreted in milk divided by $\mathrm{N}$ intake) on a per-cow basis results in reduced milk production, more $\mathrm{N}$ might actually be excreted into the environment because more cows are needed to meet the demand for dairy products (St-Pierre and Thraen, 1999). In addition, if reducing $\mathrm{N}$ excretion 
Table 1. Ingredient composition of diets with differing concentrations of alfalfa (25.0, 32.3, 50.0, 67.8, and 75.0\% of forage DM), starch (22.0, 23.2, 26.0, 28.8, and 30.0\% of DM), and $\mathrm{MP}(8.8,9.3,10.4,11.5$, and $12.0 \%$ of $\mathrm{DM})$

\begin{tabular}{|c|c|c|c|c|c|c|c|c|c|c|c|c|c|c|c|}
\hline \multirow[b]{3}{*}{ Item } & \multirow{3}{*}{$\begin{array}{l}25.0 \\
26.0 \\
10.4\end{array}$} & \multicolumn{4}{|c|}{32.3} & \multicolumn{5}{|c|}{50.0} & \multicolumn{4}{|c|}{67.8} & \multirow{3}{*}{$\begin{array}{l}75.0 \\
26.0 \\
10.4\end{array}$} \\
\hline & & \multicolumn{2}{|c|}{23.2} & \multicolumn{2}{|c|}{28.8} & \multirow{2}{*}{$\frac{22.0}{10.4}$} & \multicolumn{3}{|c|}{26.0} & \multirow{2}{*}{$\begin{array}{c}30.0 \\
10.4\end{array}$} & \multicolumn{2}{|c|}{23.2} & \multicolumn{2}{|c|}{28.8} & \\
\hline & & 9.3 & 11.5 & 9.3 & 11.5 & & 8.8 & 10.4 & 12.0 & & 9.3 & 11.5 & 9.3 & 11.5 & \\
\hline Alfalfa silage & 12.50 & 16.16 & 16.16 & 16.16 & 16.16 & 25.00 & 25.00 & 25.00 & 25.00 & 25.00 & 33.84 & 33.84 & 33.84 & 33.84 & 37.50 \\
\hline Corn silage & 37.50 & 33.84 & 33.84 & 33.84 & 33.84 & 25.00 & 25.00 & 25.00 & 25.00 & 25.00 & 16.16 & 16.16 & 16.16 & 16.16 & 12.50 \\
\hline Ground corn & 8.88 & 9.49 & 9.49 & 17.51 & 17.52 & 13.42 & 19.10 & 19.10 & 19.12 & 24.73 & 22.32 & 22.32 & 30.33 & 30.10 & 29.31 \\
\hline Soymeal, $44 \%$ CP & 5.81 & 7.11 & 6.02 & 8.00 & 7.00 & 2.39 & 2.87 & 2.99 & 2.55 & 3.64 & 0.00 & 0.00 & 0.97 & 0.40 & 0.00 \\
\hline Soypass $^{1}$ & 4.40 & 0.37 & 7.39 & 0.00 & 7.16 & 4.93 & 0.00 & 4.69 & 9.58 & 4.45 & 1.94 & 8.66 & 1.54 & 8.40 & 5.09 \\
\hline Soybean hulls & 9.42 & 16.90 & 11.05 & 8.37 & 2.14 & 15.37 & 14.00 & 9.28 & 4.81 & 3.16 & 17.01 & 10.40 & 8.40 & 2.37 & 9.10 \\
\hline Wheat middlings & 14.86 & 9.61 & 9.61 & 9.62 & 9.62 & 7.47 & 7.47 & 7.47 & 7.47 & 7.47 & 2.23 & 2.23 & 2.22 & 2.23 & 0.00 \\
\hline Urea & 0.14 & 0.09 & 0.00 & 0.00 & 0.00 & 0.00 & 0.05 & 0.00 & 0.00 & 0.00 & 0.00 & 0.00 & 0.00 & 0.00 & 0.00 \\
\hline Citrus pulp & 4.00 & 4.00 & 4.00 & 4.00 & 4.00 & 4.00 & 4.00 & 4.00 & 4.00 & 4.00 & 4.00 & 4.00 & 4.00 & 4.00 & 4.00 \\
\hline Dicalcium phosphate & 0.00 & 0.05 & 0.00 & 0.00 & 0.00 & 0.08 & 0.32 & 0.00 & 0.00 & 0.00 & 0.30 & 0.12 & 0.23 & 0.08 & 0.48 \\
\hline Other $^{2}$ & 2.49 & 2.38 & 2.44 & 2.50 & 2.56 & 2.34 & 2.19 & 2.47 & 2.47 & 2.55 & 2.20 & 2.27 & 2.31 & $\begin{array}{l}0.40 \\
2.42\end{array}$ & $\begin{array}{l}0.00 \\
2.02\end{array}$ \\
\hline
\end{tabular}

${ }^{1}$ Nonenzymatically browned soybean meal (Lignotech, Inc., Rothschild, WI).

${ }^{2} \mathrm{All}$ diets contained $0.5 \%$ animal-vegetable fat; $0.62 \%$ sodium bicarbonate; $0.41 \%$ trace mineral salt; and $0.25 \%$ premix that provided $80 \mathrm{mg} \mathrm{Zn}(\mathrm{ZnO}), 7.5 \mathrm{mg} \mathrm{Cu}\left(\mathrm{Cu}_{2} \mathrm{SO} \mathrm{O}_{4}\right), 0.3$ $\mathrm{mg} \mathrm{Se}\left(\mathrm{NaSeO}_{4}\right), 4,700 \mathrm{IU}$ vitamin A, 1,210 IU vitamin D, and $21 \mathrm{IU}$ of vitamin E/ $\mathrm{kg}$ of TMR DM. Diets also contained 0.33 to $0.64 \%$ limestone and 0.08 to $0.15 \%$ magnesium oxide. $\mathrm{DM})$, and MP $(8.8,9.3,10.4,11.5$, and $12.0 \%$ of $\mathrm{DM})$

\begin{tabular}{|c|c|c|c|c|c|c|c|c|c|c|c|c|c|c|c|}
\hline \multirow[b]{3}{*}{ Item } & \multirow{3}{*}{$\begin{array}{l}25.0 \\
26.0 \\
10.4\end{array}$} & \multicolumn{4}{|c|}{32.3} & \multicolumn{5}{|c|}{50.0} & \multicolumn{4}{|c|}{67.8} & \multirow{3}{*}{$\begin{array}{c}75.0 \\
26.0 \\
10.4\end{array}$} \\
\hline & & \multicolumn{2}{|c|}{23.2} & \multicolumn{2}{|c|}{28.8} & \multirow{2}{*}{$\begin{array}{l}22.0 \\
10.4\end{array}$} & \multicolumn{3}{|c|}{26.0} & \multirow{2}{*}{$\begin{array}{l}30.0 \\
10.4\end{array}$} & \multicolumn{2}{|c|}{23.2} & \multicolumn{2}{|c|}{28.8} & \\
\hline & & 9.3 & 11.5 & 9.3 & 11.5 & & 8.8 & 10.4 & 12.0 & & 9.3 & 11.5 & 9.3 & 11.5 & \\
\hline DM, $\%$ & 64.2 & 64.5 & 64.1 & 64.8 & 64.2 & 65.1 & 64.8 & 64.5 & 64.6 & 64.4 & 65.1 & 64.8 & 65.0 & 65.0 & 64.9 \\
\hline $\mathrm{OM}, \%$ & 93.5 & 93.5 & 93.1 & 93.4 & 93.3 & 92.6 & 92.9 & 92.7 & 92.7 & 92.7 & 92.0 & 92.0 & 92.3 & 92.2 & 91.9 \\
\hline $\mathrm{CP}, \%$ & 16.6 & 15.4 & 17.4 & 15.4 & 17.3 & 16.4 & 14.9 & 16.2 & 17.7 & 15.9 & 15.3 & 17.4 & 15.0 & 17.4 & 16.6 \\
\hline Starch, \% & 23.4 & 21.7 & 22.8 & 26.9 & 27.9 & 21.5 & 25.5 & 25.0 & 25.6 & 28.4 & 23.3 & 22.8 & 28.4 & 28.5 & 26.7 \\
\hline NDF, $\%$ & 35.0 & 37.0 & 35.1 & 33.0 & 29.7 & 36.5 & 34.2 & 33.1 & 30.9 & 29.8 & 35.5 & 32.9 & 30.1 & 27.7 & 30.0 \\
\hline Energy, Mcal/kg & 4.52 & 4.52 & 4.49 & 4.53 & 4.57 & 4.52 & 4.51 & 4.51 & 4.55 & 4.50 & 4.49 & 4.59 & 4.48 & 4.54 & 4.51 \\
\hline $\mathrm{Ca}, \%$ & 0.78 & 0.82 & 0.81 & 0.76 & 0.77 & 0.80 & 0.80 & 0.81 & 0.82 & 0.87 & 0.87 & 0.88 & 0.82 & 0.85 & 0.79 \\
\hline P, $\%$ & 0.41 & 0.37 & 0.39 & 0.39 & 0.42 & 0.36 & 0.37 & 0.37 & 0.40 & 0.37 & 0.37 & 0.38 & 0.36 & 0.37 & 0.35 \\
\hline $\mathrm{Mg}, \%$ & 0.30 & 0.30 & 0.26 & 0.34 & 0.31 & 0.30 & 0.30 & 0.30 & 0.29 & 0.30 & 0.33 & 0.33 & 0.30 & 0.29 & 0.28 \\
\hline $\mathrm{K}, \%$ & 1.44 & 1.54 & 1.57 & 1.49 & 1.53 & 1.74 & 1.64 & 1.70 & 1.72 & 1.63 & 1.86 & 1.93 & 1.75 & 1.82 & 1.90 \\
\hline \multicolumn{16}{|c|}{ Estimated protein fractions, ${ }^{1} \%$ of DM } \\
\hline RDP & 10.8 & 10.8 & 10.7 & 10.8 & 10.7 & 10.7 & 10.8 & 10.6 & 10.6 & 10.6 & 10.7 & 10.7 & 10.6 & 10.7 & 10.8 \\
\hline dRUP & 4.9 & 3.7 & 5.8 & 3.8 & 5.8 & 4.7 & 3.2 & 4.7 & 6.2 & 4.6 & 3.6 & 5.7 & 3.5 & 5.7 & 4.8 \\
\hline $\mathrm{MP}$ & 10.6 & 9.4 & 11.5 & 9.5 & 11.6 & 10.4 & 9.0 & 10.4 & 12.0 & 10.4 & 9.4 & 11.5 & 9.3 & 11.5 & 10.5 \\
\hline
\end{tabular}

${ }^{1} \mathrm{RDP}$, digestible RUP (dRUP), and MP calculated using the NRC (2001) model with measured concentrations of CP, NRC library protein kinetic values, and DMI set at $24.4 \mathrm{~kg} / \mathrm{d}$ (mean for the experiment). 
per cow reduces milk yield, the cost of not excreting that $\mathrm{N}$ into the environment becomes exceedingly high (St-Pierre and Thraen, 1999). Therefore, optimizing diets with respect to their total environmental impact requires information on $\mathrm{N}$ excretion and manure ammonia plus nutrient utilization and milk production data. This paper discusses the effects of altering dietary forage source, carbohydrate source, and concentration of MP on digestibility of major nutrients, intakes of DE and DM, and milk production of dairy cows. Dietary effects on $\mathrm{N}$ excretion and manure ammonia are discussed in a companion paper (Weiss et al., 2009).

\section{MATERIALS AND METHODS}

\section{Treatments}

The 3 main effects for this experiment were type of forage (designated alfalfa and expressed as \% of forage DM), type of carbohydrate (designated starch and expressed as \% of dietary DM), and concentration of MP (\% of dietary DM). Fifteen different diets (Table 1) were formulated from combinations of main effects within the following limits. Alfalfa ranged from 25 to $75 \%$ of the forage (the remainder was corn silage), and all diets contained $50 \%$ forage. Starch concentrations were formulated to range from 22 to $30 \%$ (Table 2), and most of the starch was supplied from dry ground corn and corn silage. Concentrations of starch and NDF in diets are negatively correlated (Armentano and Pereira, 1997). Therefore, diets differed in both NDF and starch, and effects caused by starch cannot be differentiated from those caused by NDF. Diets differed in several aspects of protein nutrition, but treatments will be discussed relative to differences in MP. All diets contained about $10.7 \%$ RDP (slight excess based on the NRC, 2001, model). The concentration of digestible RUP was altered to obtain diets that ranged from 8.8 to $12.0 \%$ MP (equivalent to 85 and $115 \%$ of MP requirement; NRC, 2001) for average milk yield at the start of the experiment. The concentrations of the main effects in the various treatments are a function of the experimental design, which is discussed in a separate paper (St-Pierre and Weiss, 2009).

A single source of corn silage (one field planted with seeds from a blend of unidentified hybrids and harvested without kernel processing) and first-cutting alfalfa silage (multiple fields harvested over a 5-d period) were used for the entire experiment (Table 3). Fifteen different pelleted concentrate mixes were used. To reduce variation, only 3 batches of each mix were made $(1$ batch $/ 2$ blocks). Diets were formulated to meet or exceed NRC (2001) requirements for minerals and vitamins.

\section{Cows and Experimental Design}

Experimental protocols were approved by The Ohio State University Agricultural Animal Care and Use Committee. Thirty-six multiparous Holstein cows averaging $128(\mathrm{SD}=22)$ DIM were used. The experimental design consisted of 6 blocks (conducted consecutively); each block was an incomplete Latin square with 6 cows and three 21-d periods, resulting in 108 observations. The treatment design was a 3 -factor central composite with 4 replicates of the center treatment (50\% alfalfa, $26 \%$ starch, and $10.4 \% \mathrm{MP}$ ), resulting in 18 treatments but only 15 diets. The replication of the center treatment allows the partitioning of the residual error into lack-of-fit and pure error components and maintains design balance and orthogonality of parameter estimates. The design structure is explained fully in St-Pierre and Weiss (2009).

Five to $7 \mathrm{~d}$ before the start of each block, cows were moved into tie stalls and fed the center diet. After the acclimation period, cows were fed their respective diet as a TMR once daily and were milked twice daily. On d 14 of each period, cows were moved to metabolism stalls for $4 \mathrm{~d}$. Cows were then moved back to tie stalls to complete the 21-d period. Then the process was repeated for each 21-d period. The metabolism stalls were in the same barn as the tie stalls and had similar dimensions; therefore, cows were not adapted to those stalls before the collection periods. The amount of TMR offered was adjusted to provide $5 \%$ orts (actual average refusal was $6.3 \%$ ) when in tie stalls and $2 \%$ (average $=3.2 \%$ ) when in metabolism stalls. Cows were weighed on $\mathrm{d} 3$ and $\mathrm{d}$ 21 of each period.

During each collection period, cows were fed once daily and milked twice daily in the metabolism stalls. Urine was collected using an external urine cup (Fellner et al., 1988) attached to the cow using an udder support harness (Nasco, Ft. Atkinson, WI). An inline sample splitter diverted approximately $5 \%$ of the urine flow into a vessel containing adequate sulfuric acid (50\% $\mathrm{vol} / \mathrm{vol}$ ) to maintain urine $\mathrm{pH}<5$. The remaining urine flowed into a large container without acid. Each morning during the collection period, feces, urine (acidified and nonacidified), and feed refusals were weighed.

\section{Sampling and Analyses}

Silages were sampled weekly and analyzed for DM $\left(100^{\circ} \mathrm{C}\right.$ for $\left.24 \mathrm{~h}\right)$ to adjust the TMR for changes in DM. Milk (a.m. and p.m.) was sampled on d 8 and 15 of each period and analyzed for fat, true protein, and lactose (B2000 Infrared Analyzer, Bentley Instruments, Chaska, MN) and MUN (Skalar SAN Plus, Skalar Inc., Norcross, GA) by DHI Cooperative Inc. (Columbus, 
WEISS ET AL.

Table 3. Nutrient composition (DM basis except when noted otherwise) of the silages $(\mathrm{n}=18 /$ silage type)

\begin{tabular}{|c|c|c|c|c|}
\hline \multirow[b]{2}{*}{ Item } & \multicolumn{2}{|c|}{ Corn silage } & \multicolumn{2}{|c|}{ Alfalfa silage } \\
\hline & Mean & $\mathrm{SD}$ & Mean & SD \\
\hline $\mathrm{DM}\left(100^{\circ} \mathrm{C}\right), \%$ & 37.6 & 1.4 & 40.4 & 3.4 \\
\hline DM (lyophilized), \% & 39.1 & 1.0 & 43.9 & 4.0 \\
\hline $\mathrm{CP}, \%$ & 7.7 & 0.6 & 24.2 & 0.8 \\
\hline ADIN, $\%$ of $\mathrm{N}$ & 4.51 & 1.01 & 6.11 & 1.11 \\
\hline NDF, \% & 37.1 & 2.6 & 36.8 & 1.7 \\
\hline IVNDFD, ${ }^{1} \%$ of NDF & 38.4 & 2.22 & 49.2 & 1.96 \\
\hline Lignin, \% & 1.7 & 0.20 & 5.2 & 0.39 \\
\hline Starch, \% & 36.2 & 2.2 & 2.1 & 0.4 \\
\hline Gross energy, Mcal/kg & 4.56 & 0.15 & 4.61 & 0.16 \\
\hline Ash, \% & 3.75 & 0.29 & 12.89 & 1.11 \\
\hline $\mathrm{Ca}, \%$ & 0.17 & 0.03 & 0.91 & 0.07 \\
\hline $\mathrm{P}, \%$ & 0.26 & 0.02 & 0.40 & 0.02 \\
\hline $\mathrm{K}, \%$ & 0.99 & 0.08 & 3.73 & 0.42 \\
\hline \multicolumn{5}{|c|}{ Particle size distribution, ${ }^{2} \%$ of wet weight } \\
\hline Top, 1.9-cm holes & 4.4 & 2.0 & 13.8 & 6.0 \\
\hline Middle, 0.8-cm holes & 62.2 & 3.0 & 45.2 & 5.4 \\
\hline Pan & 33.4 & 3.3 & 41.0 & 3.5 \\
\hline
\end{tabular}

${ }^{1}$ In vitro NDF disappearance ( $\mathrm{n}=3$ /forage type).

${ }^{2}$ Measured using 2-screen separator (Lammers et al., 1996).

$\mathrm{OH})$. Samples of feces (1\% of wet weight), acidified urine ( $5 \%$ of weight), feed refusals ( $10 \%$ of wet weight), milk ( $0.2 \%$ of weight), and feeds were taken daily during the collection period, composited, and stored in a refrigerator $\left(4^{\circ} \mathrm{C}\right)$. Urine output was the total output of acidified (corrected for acid dilution) and nonacidifed urine.

At the end of each collection period, samples of wet feces, acidified urine, and milk were analyzed (in duplicate) for Kjeldahl $\mathrm{N}$ within $24 \mathrm{~h}$ (AOAC, 2000). Other samples of silages, feed refusals, and feces were frozen $\left(-20^{\circ} \mathrm{C}\right)$, lyophilized, and ground through a 1-mm screen (Wiley Mill, Arthur H. Thomas, Philadelphia, PA). Dried and ground samples were analyzed for $\mathrm{N}(\mathrm{AOAC}, 2000), \mathrm{DM}\left(100^{\circ} \mathrm{C}\right.$ for $\left.24 \mathrm{~h}\right)$, ash $\left(500^{\circ} \mathrm{C}\right.$ overnight), NDF using amylase and sodium sulfite (Ankom Technology, 2003), starch (Weiss and Wyatt, 2000), and energy (oxygen bomb calorimeter, Model 1281, Parr Instruments, Moline, IL). Forages and feces were dry-ashed (AOAC, 2000), and concentrates and orts were digested with perchloric acid (AOAC, 2000) and then assayed for minerals using inductively coupled plasma emission spectroscopy. Silages were analyzed for sulfuric acid lignin (Ankom Technology, 2003), ADIN (AOAC, 2000), and particle size (Lammers et al., 1996). Composited silage samples (blocks 1 and 2, 3 and 4, and 5 and 6) were assayed for in vitro NDF disappearance (IVNDFD) with a 30 -h incubation period by Cumberland Valley Analytical Services (Hagerstown, MD).

\section{Statistical Analyses}

Production data collected during the last 2 wk of each period were averaged within cow and period. Energy- corrected milk was calculated (Tyrrell and Reid, 1965). Daily feed intake and milk, urine, and fecal outputs were averaged for the 4-d collection period. All data were analyzed statistically as described by St-Pierre and Weiss (2009). Briefly, the model included linear and quadratic main effects and all 2-way interactions as fixed effects. Random effects included block, period within blocks, and cows nested within block. Nonsignificant fixed effects $(P>0.10)$ were removed from the model.

\section{RESULTS AND DISCUSSION}

Overall means and ranges for response variables are shown in Table 4, and individual treatment means are shown in Tables 5 and 6 . An objective of this experiment was to derive response surfaces; therefore, equations (Tables 7 and 8), rather than means, will be discussed. Factors that affected apparent digestibility of nutrients are shown in Table 7. During the collection periods, DMI averaged $24.1 \mathrm{~kg} / \mathrm{d}$ and was affected by alfalfa (data not shown). The alfalfa effect was essentially the same as found with DMI data measured during the last 2 wk of each period (Table 6 ) and will be discussed with other production measures.

\section{Crude Protein Digestibility}

Apparent digestibility of CP averaged 63\% (Tables 4 and 5) and increased linearly as MP increased or alfalfa decreased (Table 7). The marginal effect of changing MP (i.e., the coefficient in Table 7) was much greater than the marginal effect of changing the concentration 
Table 4. Simple statistics for measured response variables

\begin{tabular}{lccc}
\hline Response variable & Mean & Minimum & Maximum \\
\hline DMI, kg/d & 24.4 & 16.2 & 29.7 \\
BW, kg & 641 & 538 & 817 \\
BW change, kg/d & -0.03 & -2.1 & 2.7 \\
Milk, kg/d & 38.3 & 28.6 & 49.7 \\
$4 \%$ FCM, kg/d & 38.0 & 25.6 & 45.8 \\
ECM, kg/d & 40.1 & 28.2 & 5.13 \\
Milk fat, \% & 4.00 & 700 & 2.13 \\
Milk fat, g/d & 1,514 & 2.47 & 3.66 \\
Milk protein, \% & 2.91 & 796 & 1,512 \\
Milk protein, g/d & 1,109 & 4.16 & 5.19 \\
Lactose, \% & 4.77 & 1,235 & 7.4 \\
Lactose, g/d & 1,823 & 60.0 & 35.6 \\
MUN, mg/dL & 12.2 & 59.9 & 72.7 \\
DM digestibility, \% & 67.7 & 57.3 & 73.5 \\
OM digestibility, \% & 68.6 & 52.1 & 72.0 \\
Energy digestibility, \% & 66.7 & 29.4 & 70.5 \\
CP digestibility, \% & 63.0 & 82.8 & 64.8 \\
NDF digestibility, \% & 51.9 & 55.7 & 97.1 \\
Starch digestibility, \% & 90.8 & 2.47 & 76.0 \\
Carbohydrate ${ }^{1}$ digestibility, \% & 68.8 & 41.5 & 3.34 \\
Digestible energy (DE), Mcal/kg & 3.02 & & 93.6 \\
DE intake, Mcal/d & 72.9 & & \\
\hline
\end{tabular}

${ }^{1}$ Carbohydrate $=$ starch + NDF.

of alfalfa; however, the typical range in dietary concentrations of alfalfa (as percent of forage) is greater than the typical range in MP concentrations. As dietary MP increased from least to greatest, digestibility of CP increased from 61.7 to $64.6 \%$ (4.7\% increase), and as alfalfa decreased from 75 to $25 \%$ of the forage, CP digestibility increased from 59.9 to $66.4 \%(9.8 \%$ increase). The MP effect on apparent $\mathrm{CP}$ digestibility was probably caused mostly by dilution of endogenous fecal N (Holter and Reid, 1959). The alfalfa effect was probably a result of differences in digestibility of $\mathrm{CP}$ provided by alfalfa or soybean meal. Crude protein from soybean meal is usually more digestible than $\mathrm{CP}$ from alfalfa silage (Ruppert et al., 2003; Wattiaux and Karg, 2004b; Brito and Broderick, 2006), and as alfalfa in diets increased, the concentration of soybean meal decreased (Table 1). The alfalfa silage in our study did not appear to be heat-damaged based on ADIN concentration (Table 3). Treatment effects on CP digestibility relative to $\mathrm{N}$ excretion are discussed in a companion paper (Weiss et al., 2009), but digestible protein also contributes to dietary DE. Assuming digestible protein has an energy value of $5.6 \mathrm{Mcal} / \mathrm{kg}$ (NRC, 2001), the 6.5 percentage-unit increase in $\mathrm{CP}$ digestibility as alfalfa decreased from greatest to least concentration would increase dietary DE by about $0.06 \mathrm{Mcal} / \mathrm{kg}$ (about $2 \%$ of the average DE concentration in this experiment).

\section{Carbohydrate Digestibility}

Apparent digestibility of the major carbohydrate fractions, NDF and starch, and their sum (designated as total CHO) averaged 51.9, 90.8, and $68.8 \%$, respectively (Tables 4 and 5), and were affected by starch and alfalfa treatments (Table 7). As dietary starch increased, digestibility of NDF linearly decreased but digestibility of starch and total CHO linearly increased. Conversely, as alfalfa increased, digestibility of starch decreased linearly but digestibility of NDF increased linearly and digestibility of total $\mathrm{CHO}$ increased and then reached a plateau (quadratic response). A similar 5-percentageunit increase in NDF digestibility occurred when alfalfa increased from its least to greatest concentrations and when starch changed from its greatest to least concentrations. Given that source of NDF changed as alfalfa changed, differences in the inherent digestibility of the NDF from the various sources likely explain the alfalfa effect on NDF digestibility. For the least alfalfa treatment, 13,40 , and $47 \%$ of the NDF came from alfalfa, corn silage, and concentrate, respectively; whereas, for the greatest alfalfa treatment, alfalfa, corn silage, and concentrate provided 46,15 , and $39 \%$ of the total NDF. The IVNDFD of corn silage was much less than that of the alfalfa (38.4 vs. 49.2\%). Assuming forage type had no effect on the digestibility of the NDF provided by the concentrate, the difference in IVNDFD for the 2 forages would yield an estimated difference in total diet NDF digestibility between the greatest and least alfalfa diets of about 2.5 percentage units as compared with the measured difference of about 5 percentage units. The digestibility of forage NDF is affected by numerous factors such as hybrid, growing conditions, and maturity. Therefore, increasing alfalfa and reducing corn silage might not always increase NDF digestibility; however, 
Table 5. Least square means for digestibility coefficients and daily intakes of nutrients during the 4-d collection period by cows fed diets with differing concentrations of alfalfa $(25.0,32.3,50.0,67.8$, and $75.0 \%$ of forage DM), starch $(22.0,23.2,26.0,28.8$, and $30.0 \%$ of DM), and MP $(8.8,9.3,10.4,11.5$, and $12.0 \%$ of DM)

\begin{tabular}{|c|c|c|c|c|c|c|c|c|c|c|c|c|c|c|c|c|}
\hline \multirow[b]{3}{*}{ Item } & \multirow{3}{*}{$\begin{array}{c}25.0 \\
26.0 \\
10.4\end{array}$} & \multicolumn{4}{|c|}{32.3} & \multicolumn{5}{|c|}{50.0} & \multicolumn{4}{|c|}{67.8} & \multirow{3}{*}{$\begin{array}{l}75.0 \\
26.0 \\
10.4\end{array}$} & \multirow[b]{3}{*}{ SEM } \\
\hline & & \multicolumn{2}{|c|}{23.2} & \multicolumn{2}{|c|}{28.8} & \multirow{2}{*}{$\begin{array}{l}22.0 \\
10.4\end{array}$} & \multicolumn{3}{|c|}{26.0} & \multirow{2}{*}{$\begin{array}{c}30.0 \\
10.4\end{array}$} & \multicolumn{2}{|c|}{23.2} & \multicolumn{2}{|c|}{28.8} & & \\
\hline & & 9.3 & 11.5 & 9.3 & 11.5 & & 8.8 & 10.4 & 12.0 & & 9.3 & 11.5 & 9.3 & 11.5 & & \\
\hline \multicolumn{17}{|l|}{ Intake } \\
\hline $\mathrm{DM}, \mathrm{kg}$ & 22.9 & 23.8 & 24.4 & 23.8 & 25.6 & 25.0 & 23.3 & 24.2 & 23.9 & 24.3 & 24.3 & 25.4 & 24.8 & 23.9 & 24.3 & 0.73 \\
\hline DE, Mcal & 68.3 & 72.2 & 73.2 & 71.4 & 73.6 & 72.9 & 70.2 & 72.7 & 73.6 & 74.8 & 71.3 & 78.8 & 73.4 & 75.3 & 73.9 & 3.12 \\
\hline $\mathrm{NDF}, \mathrm{kg}$ & 7.93 & 8.65 & 8.36 & 7.82 & 6.87 & 8.99 & 8.08 & 7.97 & 7.31 & 7.24 & 8.64 & 8.32 & 7.62 & 6.57 & 7.39 & 0.30 \\
\hline Starch, kg & 5.29 & 4.95 & 5.43 & 6.22 & 6.42 & 5.34 & 5.96 & 6.02 & 6.08 & 6.64 & 5.73 & 5.61 & 7.07 & 6.91 & 6.42 & 0.25 \\
\hline $\mathrm{CP}, \mathrm{kg}$ & 3.95 & 3.76 & 4.39 & 3.74 & 4.25 & 4.06 & 3.52 & 3.95 & 4.18 & 3.93 & 3.72 & 4.50 & 3.68 & 4.12 & 4.09 & 0.13 \\
\hline \multicolumn{17}{|l|}{ Digestibility, ${ }^{1} \%$} \\
\hline $\mathrm{DM}$ & 66.2 & 67.1 & 67.6 & 67.2 & 68.0 & 66.2 & 67.1 & 67.8 & 68.4 & 69.5 & 66.3 & 68.4 & 67.3 & 70.2 & 67.9 & 0.78 \\
\hline Energy & 65.1 & 66.6 & 66.9 & 66.3 & 67.6 & 65.6 & 66.3 & 66.8 & 67.7 & 68.2 & 65.0 & 67.9 & 66.1 & 68.8 & 67.1 & 0.91 \\
\hline Starch & 92.2 & 91.3 & 91.3 & 90.2 & 91.4 & 88.3 & 91.5 & 91.5 & 90.9 & 92.1 & 90.2 & 89.3 & 91.4 & 90.6 & 88.9 & 1.13 \\
\hline $\mathrm{NDF}$ & 45.6 & 53.0 & 50.8 & 51.3 & 48.5 & 55.3 & 49.9 & 53.3 & 50.1 & 50.7 & 53.5 & 56.0 & 52.5 & 49.4 & 53.9 & 2.07 \\
\hline Total CHO & 64.3 & 67.1 & 66.7 & 68.3 & 68.8 & 67.5 & 67.6 & 69.7 & 68.9 & 70.5 & 68.2 & 69.6 & 71.3 & 70.7 & 70.1 & 1.23 \\
\hline $\mathrm{CP}$ & 67.6 & 64.5 & 67.3 & 64.1 & 65.7 & 61.9 & 62.5 & 62.5 & 62.1 & 65.2 & 58.8 & 62.0 & 58.5 & 64.4 & 60.3 & 1.48 \\
\hline DE, Mcal/kg & 2.95 & 3.01 & 2.99 & 3.01 & 3.09 & 2.98 & 2.98 & 3.01 & 3.08 & 3.09 & 2.92 & 3.11 & 2.96 & 3.12 & 3.02 & 0.06 \\
\hline
\end{tabular}

${ }^{1}$ Total $\mathrm{CHO}=$ starch $+\mathrm{NDF} ; \mathrm{DE}=$ digestible energy.

Table 6. Least squares means for production measures during the last 2 wk of each period of cows fed diets with differing concentrations of alfalfa (25.0, 32.3, $50.0,67.8$, and $75.0 \%$ of forage DM), starch $(22.0,23.2,26.0,28.8$, and $30.0 \%$ of DM), and MP $(8.8,9.3,10.4,11.5$, and $12.0 \%$ of DM)

\begin{tabular}{|c|c|c|c|c|c|c|c|c|c|c|c|c|c|c|c|c|}
\hline \multirow[b]{3}{*}{ Item } & \multirow{3}{*}{$\begin{array}{c}25.0 \\
26.0 \\
10.4\end{array}$} & \multicolumn{4}{|c|}{32.3} & \multicolumn{5}{|c|}{50.0} & \multicolumn{4}{|c|}{67.8} & \multirow{3}{*}{$\begin{array}{l}75.0 \\
26.0 \\
10.4\end{array}$} & \multirow[b]{3}{*}{ SEM } \\
\hline & & \multicolumn{2}{|c|}{23.2} & \multicolumn{2}{|c|}{28.8} & \multirow{2}{*}{$\begin{array}{c}22.0 \\
10.4\end{array}$} & \multicolumn{3}{|c|}{26.0} & \multirow{2}{*}{$\begin{array}{c}30.0 \\
10.4\end{array}$} & \multicolumn{2}{|c|}{23.2} & \multicolumn{2}{|c|}{28.8} & & \\
\hline & & 9.3 & 11.5 & 9.3 & 11.5 & & 8.8 & 10.4 & 12.0 & & 9.3 & 11.5 & 9.3 & 11.5 & & \\
\hline DMI, $\mathrm{kg} / \mathrm{d}$ & 23.2 & 24.0 & 24.1 & 24.1 & 24.3 & 25.0 & 23.4 & 24.5 & 24.7 & 24.0 & 25.1 & 24.9 & 25.1 & 24.3 & 25.2 & 0.64 \\
\hline Milk, $\mathrm{kg} / \mathrm{d}$ & 38.0 & 37.9 & 38.4 & 37.4 & 39.2 & 37.6 & 36.3 & 38.3 & 39.1 & 37.9 & 38.6 & 39.5 & 38.0 & 39.1 & 37.0 & 1.11 \\
\hline $\mathrm{ECM}, \mathrm{kg} / \mathrm{d}$ & 38.6 & 38.4 & 41.5 & 36.9 & 38.0 & 41.2 & 37.9 & 40.2 & 41.3 & 41.7 & 39.9 & 41.6 & 41.3 & 40.6 & 42.0 & 1.57 \\
\hline Fat, $\%$ & 3.82 & 3.83 & 4.30 & 3.88 & 3.49 & 4.32 & 4.07 & 3.89 & 4.05 & 4.35 & 3.92 & 3.87 & 4.38 & 4.04 & 4.15 & 0.267 \\
\hline Fat, $g / d$ & 1,430 & 1,423 & 1,622 & 1,346 & 1.316 & 1,638 & 1,437 & 1,501 & 1,578 & 1.614 & 1,459 & 1,558 & 1,641 & 1,556 & 1.621 & 99.7 \\
\hline Protein, \% & 2.88 & 2.88 & 2.99 & 2.87 & 2.86 & 2.87 & 2.92 & 2.92 & 2.87 & 2.97 & 2.90 & 2.85 & 2.90 & 2.96 & 2.90 & 0.071 \\
\hline Protein, g/d & 1,073 & 1,072 & 1,110 & 1,007 & 1,110 & 1,090 & 1,030 & 1,136 & 1,125 & 1,132 & 1,113 & 1,159 & 1,083 & 1,131 & 1,154 & 54.0 \\
\hline Lactose, \% & 4.76 & 4.67 & 4.79 & 4.69 & 4.82 & 4.72 & 4.71 & 4.80 & 4.69 & 4.80 & 4.85 & 4.83 & 4.73 & $3 \quad 4.81$ & 4.74 & 0.060 \\
\hline Lactose, $\mathrm{g} / \mathrm{d}$ & 1,780 & 1,731 & 1,793 & 1,631 & 1,884 & 1,827 & 1,671 & 1,879 & 1,837 & 1,836 & 1,866 & 1,976 & 1,735 & 1,841 & 1,850 & 77.7 \\
\hline MUN, mg/dL & 12.2 & 11.9 & 14.1 & 10.7 & 13.9 & 14.5 & 11.3 & 11.6 & 13.5 & 12.1 & 11.2 & 13.4 & 11.2 & 12.3 & 10.7 & 1.23 \\
\hline
\end{tabular}


in vivo NDF digestibility has often increased as the ratio of alfalfa silage to corn silage increased (Ruppert et al., 2003; Brito and Broderick, 2006).

The likely reason for the negative effect of increasing starch on NDF digestibility was via alterations in the rumen environment (e.g., $\mathrm{pH}$ ) and its microbial population. Replacing fiber with readily fermentable carbohydrates often reduces fiber digestibility (Putnam and Loosli, 1959; Valadares Filho et al., 2000). Digestibility of NDF often increases when various byproducts replace corn grain in diets (Ipharraguerre and Clark, 2003; Voelker and Allen, 2003b). In those studies, a single byproduct replaced corn so that both concentration of starch and source of NDF changed in a systematic manner and either source of NDF or changes in rumen conditions could be responsible for effects on NDF digestibility. In this study, sources of NDF did not systematically change as starch concentrations increased (Table 1); therefore, the effect of starch on NDF digestibility was more likely via reduction in rumen $\mathrm{pH}$ and alteration of microbial population than changes in source of NDF.

Treatment effects on starch digestibility were modest; when either starch or alfalfa increased from least to greatest concentrations, starch digestibility either increased 1.5 percentage units or decreased 1.7 percentage units, respectively. As alfalfa increased, source of starch changed systematically (28 and $82 \%$ of the starch was from corn grain in the least to greatest alfalfa diets, respectively). The alfalfa effect implies that the starch from dry corn grain was slightly less digestible than the starch from high-moisture corn in the corn silage and the starch from the wheat middlings. In further support of this conclusion, when dietary concentrations of corn grain and corn silage were regressed on starch digestibility, the slope was negative for grain and positive for silage (data not shown). The reason for the starch effect on starch digestibility is less clear. Increasing starch concentrations could increase apparent starch digestibility because of dilution of endogenous (bacterial) fecal starch (Firkins et al., 2001). The sources of starch also changed as starch concentrations changed ( 45 and $62 \%$ of the starch was provided by corn grain for the least to greatest starch diets). Based on the alfalfa treatment effect, the change in starch sources as dietary starch increased should have resulted in a decrease in starch digestibility, but perhaps the dilution of endogenous fecal starch was greater than the small effect of change in starch source.

Digestibility of the combined carbohydrate fraction increased 2.5 percentage units as starch concentrations increased from 22 to $30 \%$ of the diet. The concentration of carbohydrate in the diet averaged $57.9 \%$ and did not change as starch concentration changed. A 2.5 percentage-unit increase in carbohydrate digestibility would increase dietary DE by $0.07 \mathrm{Mcal} / \mathrm{kg}$ (assuming carbohydrate has $4.2 \mathrm{Mcal} / \mathrm{kg}$; NRC, 2001), which is equivalent to about $2.2 \%$ of the mean DE concentration. Digestibility of the CHO fraction increased about 4.2 percentage units as alfalfa increased from 25 to $67 \%$ of the forage (calculated maximum from the quadratic equation) and then remained essentially the same up to $75 \%$ alfalfa. The change in carbohydrate digestibility over the range in alfalfa treatments would increase DE concentration by about $0.1 \mathrm{Mcal} / \mathrm{kg}$ or $3.5 \%$ of the mean DE concentration.

\section{Energy Digestibility}

The average apparent digestibility of DM and energy was approximately $68 \%$ (Table 4) and was affected similarly by starch, alfalfa, protein, and the protein by starch interaction (Table 7). Because similar treatment effects were observed, only treatment effects on DE concentrations will be discussed. Increasing the concentration of starch linearly $(P<0.05)$ increased the concentration of DE. The reason for that effect is that as starch concentration increased, the concentration of NDF decreased concomitantly, and starch had an average digestibility of $91 \%$ and NDF digestibility averaged $52 \%$. Even though starch and NDF concentrations varied substantially among treatments (from the least to greatest starch treatments, starch concentration increased $35 \%$ and NDF decreased $22 \%$ ), the concentration of $\mathrm{DE}$ changed by only $2.5 \%$ over the range in starch treatments. This very modest change in DE concentration is likely the reason for the lack of starch effects on production measures (discussed in the following). It also means that NDF from byproducts can replace a substantial amount of starch without greatly affecting DE concentrations.

The concentration of $\mathrm{DE}$ was also affected by the interaction of MP with alfalfa (Figure 1). Assuming average starch concentrations, at low alfalfa and low MP, the calculated (using the equation in Table 7) DE was $2.8 \mathrm{Mcal} / \mathrm{kg}$ (8\% less than overall mean DE). All other diets with extreme concentrations of MP or alfalfa (i.e., greatest and least concentrations) had estimated DE concentrations within $2 \%$ of the mean DE. Low CP digestibility is the major reason for the low DE concentration of the greater alfalfa, lesser MP diets. At the least concentration of MP and greatest concentration of alfalfa, calculated CP digestibility was $58 \%$ compared with $67 \%$ for the greatest MP, least alfalfa diet. The reason for the significant interaction for $\mathrm{DE}$, but not for $\mathrm{CP}$ digestibility, is that $\mathrm{DE}$ is an aggregated expression of gross energy and digestibility of all nutrients. The effects of alfalfa on carbohydrate digestion in combination 
Dी Table 7. Effects of varying concentrations of protein and starch and type of forage in the diet on nutrient digestibility and the concentration and intake of digestible energy by lactating cows

\begin{tabular}{|c|c|c|c|c|c|c|c|c|}
\hline \multirow[b]{2}{*}{ Dependent variable } & \multirow[b]{2}{*}{ Intercept } & \multirow[b]{2}{*}{ Alfalfa } & \multirow[b]{2}{*}{ Alfalfa $\times$ Alfalfa } & \multirow[b]{2}{*}{ MP } & \multirow[b]{2}{*}{ Starch } & \multirow[b]{2}{*}{ Alfalfa $\times \mathrm{MP}$} & \multicolumn{2}{|c|}{ Error $^{2}$} \\
\hline & & & & & & & RMSE & CowSE \\
\hline $\mathrm{DM}, \%$ & $68.4(7.70)$ & $-0.257(0.141)$ & NS & $-0.767(0.708)$ & $0.237(0.0748)$ & $0.0268(0.0135)$ & 1.51 & 1.26 \\
\hline Energy, \% & $68.6(8.81)$ & $-0.267(0.161)$ & NS & $-0.693(0.809)$ & $0.179(0.0861)$ & $0.0271(0.0155)$ & 1.71 & 1.41 \\
\hline $\mathrm{CP}, \%$ & $60.3(4.00)$ & $-0.135(0.0227)$ & NS & $0.914(0.365)$ & NS & NS & 3.29 & 0.980 \\
\hline NDF, $\%$ & $61.4(5.57)$ & $0.0937(0.0327)$ & NS & NS & $-0.546(0.203)$ & NS & 4.26 & 2.18 \\
\hline Starch, \% & $87.6(2.84)$ & $-0.0347(0.0161)$ & NS & NS & $0.193(0.101)$ & NS & 2.14 & 1.34 \\
\hline Carbohydrate, \% & $50.5(4.43)$ & $0.311(0.131)$ & $-0.00230(0.00129)$ & NS & $0.311(0.119)$ & NS & 2.49 & 1.32 \\
\hline $\mathrm{DE}, \mathrm{Mcal} / \mathrm{kg}$ of DM & $3.37(0.474)$ & $-0.0198(0.00869)$ & NS & $-0.0570(0.0435)$ & $0.00841(0.00467)$ & $0.00194(0.000833)$ & 0.0937 & 0.0639 \\
\hline DE intake, Mcal/d & $54.8(6.55)$ & $0.0864(0.0357)$ & NS & $1.33(0.574)$ & NS & NS & 4.23 & 5.41 \\
\hline
\end{tabular}

${ }^{1}$ The full model included linear and quadratic effects of dietary alfalfa (range was 25 to $75 \%$ of forage DM), starch (range was 22 to $30 \%$ of DM), MP (range was 8.8 to $12.0 \%$ of $\mathrm{DM})$, and all 2-way interactions. The final models include only effects that were significant $(P<0.10)$. Values in parentheses are SE of the coefficient.

${ }^{2} \mathrm{RMSE}=$ root mean square error; CowSE $=$ square root of the variance due to cows. When applied to a group of cows, the prediction error $=[\mathrm{RMSE}+($ CowSE $/ \sqrt{ } n)]$, where $n$

$=$ number of cows in the group to which the equations are applied.

Table 8. Effects of varying concentrations of protein and starch and type of forage in the diet on production measures of lactating cows ${ }^{1}$

\begin{tabular}{|c|c|c|c|c|c|c|c|c|c|}
\hline \multirow[b]{2}{*}{$\begin{array}{l}\text { Dependent } \\
\text { variable }\end{array}$} & \multirow[b]{2}{*}{ Intercept } & \multirow[b]{2}{*}{ Alfalfa (A) } & \multirow[b]{2}{*}{ MP } & \multirow[b]{2}{*}{$\mathrm{MP} \times \mathrm{MP}$} & \multirow[b]{2}{*}{ Starch (S) } & \multirow[b]{2}{*}{$A \times S$} & \multirow[b]{2}{*}{$\mathrm{S} \times \mathrm{S}$} & \multicolumn{2}{|c|}{ Error $^{2}$} \\
\hline & & & & & & & & RMSE & CowSE \\
\hline DMI, $\mathrm{kg} / \mathrm{d}$ & $22.9(0.57)$ & $0.031(0.0082)$ & NS & NS & NS & NS & NS & 0.933 & 2.06 \\
\hline Milk, $\mathrm{kg} / \mathrm{d}$ & $31.4(2.21)$ & NS & $0.67(0.20)$ & NS & NS & NS & NS & 1.41 & 3.14 \\
\hline $\mathrm{ECM}, \mathrm{kg} / \mathrm{d}$ & $29.1(4.08)$ & $0.072(0.023)$ & $0.71(0.37)$ & NS & NS & NS & NS & 2.85 & 2.79 \\
\hline Fat, g/d & $3,017(957)$ & $-27.0(18.3)$ & NS & NS & $-66.1(36.4)$ & $1.20(0.70)$ & NS & 192.5 & 146.8 \\
\hline Protein, g/d & $-1,505(1,028)$ & $1.275(0.6176)$ & 465 (199) & $-21.0(9.58)$ & NS & NS & NS & 73.0 & 86.4 \\
\hline Lactose, $\mathrm{g} / \mathrm{d}$ & $-3,300(1,572)$ & $2.143(0.917)$ & $906.5(304.1)$ & $-40.5(14.7)$ & NS & NS & NS & 111.7 & 180.1 \\
\hline MUN, mg/dL & $63.7(18.1)$ & $-0.0255(0.0108)$ & $0.858(0.171)$ & NS & $-4.42(1.38)$ & NS & $0.0819(0.026)$ & 1.20 & 3.44 \\
\hline
\end{tabular}

${ }^{1}$ The full model included linear and quadratic effects of dietary alfalfa (ranged from 25 to $75 \%$ of forage DM), MP (ranged from 8.8 to $12.0 \%$ of DM), starch (ranged from 22 to $30 \%$ of DM), and all 2-way interactions. The final models shown include only effects that were significant $(P<0.10)$. Values in parentheses are the SE of the coefficient.

${ }^{2} \mathrm{RMSE}=$ root mean square error; CowSE $=$ square root of the variance due to cows. When applied to a group of cows, the prediction error $=[\mathrm{RMSE}+($ CowSE $/ \sqrt{ } n)]$, where $n$ $=$ number of cows in the group to which the equations are applied. 


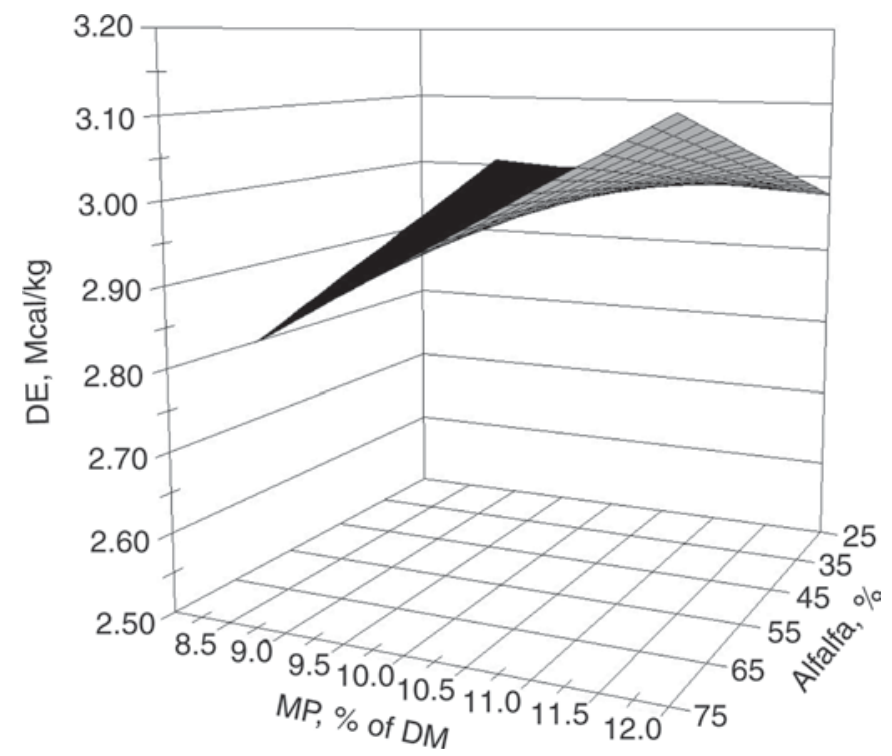

Figure 1. Changes in concentration of digestible energy (DE) as concentrations of MP and alfalfa silage (\% of forage DM) change. The response surface shown is for the mean concentration of dietary starch ( $26 \%$ of dietary DM). The equation for the response surface is DE $=$ $3.37+0.00841 \times$ Starch $-0.0198 \times$ Alfalfa $-0.057 \times \mathrm{MP}+0.00194$ $\times$ Alfalfa $\times$ MP.

with the effects of MP and alfalfa on CP digestibility likely caused the interaction. When MP concentrations are low and a substantial amount of the protein is from alfalfa, energy, not just MP, might limit production.

\section{Intake of DM and Digestible Energy}

Dry matter intake averaged $24.4 \mathrm{~kg} / \mathrm{d}$ during the last 2 wk of each period (Tables 4 and 6) and increased linearly as alfalfa increased (Table 8). No other treatment effects or interactions were observed. Changing from the diet with the least concentration of alfalfa to the diet with the greatest concentration increased DMI by about $1.5 \mathrm{~kg} / \mathrm{d}$. Previous studies (Onetti et al., 2002; Brito and Broderick, 2006) in which the alfalfa and corn silage had similar NDF concentrations found similar linear increases in DMI as alfalfa replaced corn silage. Regulation of DMI by ruminants is extremely complex, but it can be simplified to 2 major factors: fill and energy supply (Conrad et al., 1964). Increasing concentrations of forage NDF can increase fill and depress DMI, but the corn silage and alfalfa in this study had essentially the same concentration of NDF (37\%), and concentrations of forage NDF did not differ between treatments (approximately $18.5 \%$ of dietary DM). Forages with greater IVNDFD are associated with greater DMI by dairy cows (Oba and Allen, 1999), and the greater in vivo NDF digestibility with greater alfalfa diets (similar to the IVNDFD) could result in less fill and greater DMI. If supply of DE regulated DMI, cows fed increasing alfalfa would be expected to have greater DMI because as alfalfa increased, the concentration of $\mathrm{DE}$ in the diet decreased. Increasing alfalfa was associated with both an increase in DMI and an increase in DE intake (discussed in the following), which suggests that the increase in NDF digestibility allowed cows to consume more DM and DE.

Dietary CP often has a positive relationship with DMI (reviewed by Allen, 2000). A hypothesized mode of action for a protein effect on DMI is via enhanced digestibility caused by increased RDP. In this study, RDP was held constant and no relationship was observed $(P=0.52)$ between DMI and MP even though increasing MP generally increased the digestibility of DM and energy (Table 7). Increasing starch concentration (with a concomitant decrease in NDF) did not affect DMI, whereas in some studies, increasing starch was associated with a decrease in DMI (reviewed by Allen, 2000). Negative effects on DMI were usually only observed when the concentration of rumen-digestible starch exceeded about $20 \%$ of diet DM. The maximum concentration of rumen-degradable starch in our diets was likely less than that (apparent ruminal starch digestibility averages $52 \%$ for dry ground corn; Firkins et al., 2001). In addition, dietary starch in our study was altered by replacing corn with nonforage fiber sources such as soyhulls and wheat middlings. The majority of studies have shown no relationship between DMI and the concentration of nonforage fiber sources (Allen, 2000).

Intake of DE averaged $73 \mathrm{Mcal} / \mathrm{d}$ (Tables 4 and 6) and increased linearly as alfalfa or MP increased (Table 8). Over the range in alfalfa and MP concentrations, DE intake increased about $4 \mathrm{Mcal} / \mathrm{d}$. The treatment effects were additive so that over the entire range of treatments, DE intake could differ by about $8 \mathrm{Mcal} / \mathrm{d}$ or about $11 \%$ of mean DE intake (i.e., low alfalfa and low MP vs. high alfalfa and high MP).

\section{Milk Yield and Composition}

Concentrations of milk fat, protein, and lactose were not affected by any main effects or interactions. However, all main effects linearly (starch also had a quadratic effect) affected the concentration of MUN. Increasing alfalfa reduced MUN, probably because increasing alfalfa caused a reduction in intake of digestible protein. Increasing MP increased MUN as expected (Broderick and Clayton, 1997). The concentration of MUN decreased as starch concentration increased from 22 to approximately $27 \%$ and then essentially reached 
a plateau. Increasing concentrations of starch (usually with a concomitant decrease in fiber) usually decreases MUN (Valadares Filho et al., 2000).

Dietary starch varied from 22 to $30 \%$ of the DM but had little effect on production measures (Tables 6 and 8), which agrees with most other studies in which starch concentrations were altered by replacing corn grain with high-fiber byproducts (Voelker and Allen, 2003a; Beckman and Weiss, 2005; Cabrita et al., 2007). An interaction between starch and alfalfa was observed for milk fat yield (Figure 2). When diets contained substantial concentrations of alfalfa, starch had little effect on fat yield, but in diets with substantial concentrations of corn silage, increasing starch reduced fat yield. Conversely, at low starch concentrations, increasing alfalfa had no effect on fat yield, but with greater starch concentrations, increasing alfalfa increased fat yield. Increasing the concentration of alfalfa linearly increased yields of ECM, protein, and lactose $(P<$ $0.05)$. Increasing dietary alfalfa from least to greatest concentrations increased ECM, protein, and lactose yields by approximately $3.6 \mathrm{~kg} / \mathrm{d}, 60 \mathrm{~g} / \mathrm{d}$, and $100 \mathrm{~g} / \mathrm{d}$, respectively. Most of these responses are probably a result of increased DMI as alfalfa increased. In experiments with high-producing cows (Onetti et al., 2002; Ruppert et al., 2003; Wattiaux and Karg, 2004a; Brito and Broderick, 2006), replacing corn silage with alfalfa silage has consistently increased milk fat yield, but effects on yields of milk and milk protein have been variable.

Increasing dietary MP linearly increased yields of milk and ECM, but a quadratic relationship was observed for yields of protein and lactose $(P<0.05)$. Those yields increased as MP increased and reached their maximums when diets contained approximately $11 \%$ MP. Based on the NRC (2001) model, diets provided between approximately 85 and $115 \%$ of the MP requirement. Therefore, we expected quadratic relationships between MP and milk and milk component yields (i.e., increasing until the MP requirement was met and then plateauing). However, change in product yields was generally much less than anticipated based on modeled or measured change in protein and energy supplies. Supply of DE increased linearly as both MP and alfalfa increased (Table 4), as did yield of ECM (Table 5). The linear response in yield of ECM and DE intake suggests that the increased milk yield to increasing MP supply might be a function of energy supply rather than protein supply. Intake of $\mathrm{DE}$ increased about $8 \mathrm{Mcal} / \mathrm{d}$ as diets changed from the least protein and least alfalfa to the greatest protein and greatest alfalfa. Over that same range in diets, yield of ECM increased $3.1 \mathrm{~kg} / \mathrm{d}$, but an increase in DE intake of 8 $\mathrm{Mcal} / \mathrm{d}$ should be adequate to support an increase of

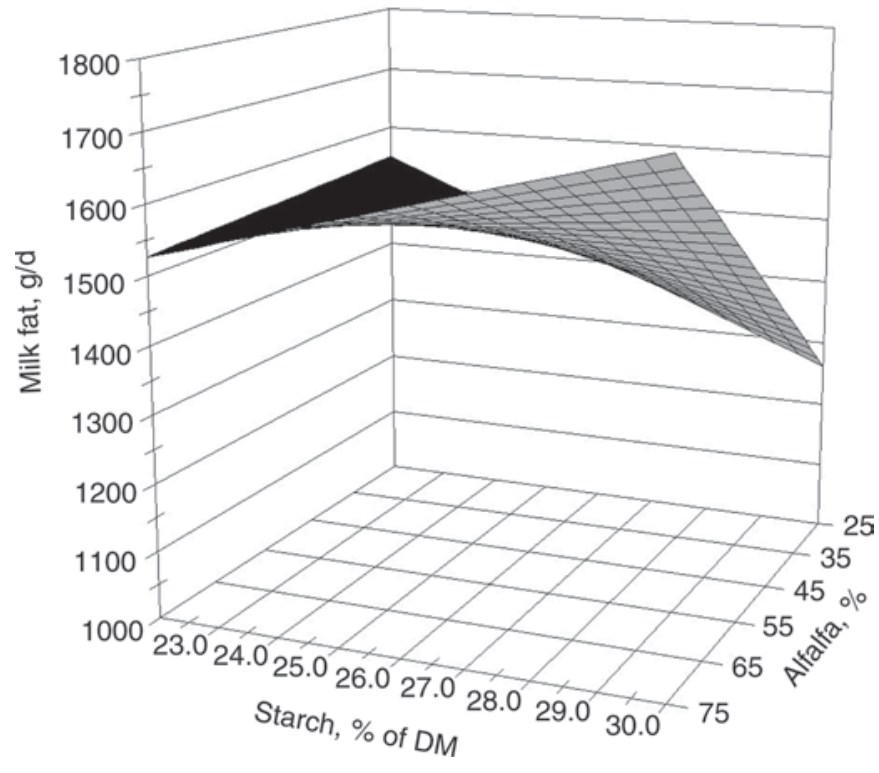

Figure 2. Changes in yield of milk fat as concentrations of starch and alfalfa silage ( $\%$ of forage DM) change. The equation for the response surface is Fat yield $=3,017-27.0 \times$ Alfalfa $-66.1 \times$ Starch $+1.20 \times$ Alfalfa $\times$ Starch.

$5.6 \mathrm{~kg} / \mathrm{d}$ of ECM (NRC, 1989). Some of the additional energy supply might have been retained in tissue rather than secreted as milk, or the efficiency of converting $\mathrm{DE}$ to $\mathrm{NE}_{\mathrm{L}}$ was less than expected. Body weight change averaged $-0.03 \mathrm{~kg} / \mathrm{d}$ (Table 4 ; not affected by treatment and not different from 0); however, in short-term experiments, changes in $\mathrm{BW}$ might not be adequate to assess energy retention. Because of DMI, MP supply increased about $160 \mathrm{~g} / \mathrm{d}$ as alfalfa increased from 25 to $75 \%$ of the forage. Using the NRC (2001) efficiency factor, an increase of $160 \mathrm{~g} / \mathrm{d}$ of MP should support about $100 \mathrm{~g} / \mathrm{d}$ more milk protein, but the actual response was $60 \mathrm{~g} / \mathrm{d}$. We hypothesized that yield of milk protein would increase and then plateau as dietary MP increased above $10.6 \%$ (i.e., $100 \%$ of the NRC, 2001, MP requirement). The mathematically derived maximum for milk protein yield in this experiment occurred at $11 \% \mathrm{MP}$. Yield of milk protein increased $93 \mathrm{~g} / \mathrm{d}$ as MP increased from 8.8 to $10.4 \%$, but the NRC model estimated that the increase should have been about $250 \mathrm{~g} / \mathrm{d}$. In a previous experiment, milk protein yield increased about $80 \mathrm{~g} / \mathrm{d}$ as NRC MP (calculated from data in the paper) increased from approximately $9.1 \%$ (diet with $13.5 \% \mathrm{CP}$ ) to $10.9 \%$ (for the diet with $16.5 \%$ $\mathrm{CP}$ ) of diet DM (Colmenero and Broderick, 2006). The NRC model estimated an approximate $300-\mathrm{g} / \mathrm{d}$ increase in milk protein yield for that experiment. Reasons for the difference include errors in the NRC model (i.e., underestimated the difference in supply of MP among diets, overestimated MP requirements, or used improp- 
er efficiency factors for converting MP to milk protein) and possible differences in the profile of absorbed amino acids. Furthermore, the duration of the periods might not have been long enough for the treatment effects to fully manifest themselves.

\section{CONCLUSIONS}

Cows were fed an array of diets that varied in type of forage and concentrations of starch and MP. Those factors often affected digestibility and production measures, but few interactions were observed between main effects. Increasing dietary starch from 22 to $30 \%$ of the DM had either no or minor effects on nutrient digestibility and DMI, and this translated into no or minor effects on yields of milk and milk components. Dry matter intake increased as alfalfa increased, perhaps because of increased fiber digestibility. Although energy digestibility was lesser when diets contained a high proportion of alfalfa, the increase in DMI was great enough to result in an increase in DE intake, which resulted in increased yields of milk and milk components. Increasing MP concentrations increased yields of ECM and milk components probably because of increased intake of DE (mostly because of increased protein digestibility) and increased intake of MP. The maximum yields of ECM occurred with the diets containing maximum alfalfa ( $75 \%$ of the forage) and maximum MP (12\%). Maximum yield of milk protein occurred with maximum alfalfa and with about $11 \% \mathrm{MP}$.

\section{ACKNOWLEDGMENTS}

Salaries and research support were provided by state and federal funds appropriated to the Ohio Agricultural Research and Development Center, The Ohio State University. This project was supported by National Research Initiative Competitive Grant no. 2005-3520615263 from the USDA Cooperative State Research, Education, and Extension. Manuscript 4/09AS.

\section{REFERENCES}

Allen, M. S. 2000. Effects of diet on short-term regulation of feed intake by lactating dairy cows. J. Dairy Sci. 83:1598-1624.

Ankom Technology. 2003. Method for Determining Neutral Detergent Fiber (aNDF). Ankom Technology, Macedon, NY.

Armentano, L., and M. Pereira. 1997. Measuring the effectiveness of fiber by animal response trials. J. Dairy Sci. 80:1416-1425.

AOAC. 2000. Official Methods of Analysis of AOAC International. Vol. I and II. 17th ed. AOAC International, Gaithersburg, MD.

Beckman, J. L., and W. P. Weiss. 2005. Nutrient digestibility of diets with different fiber to starch ratios when fed to lactating dairy cows. J. Dairy Sci. 88:1015-1023.

Brito, A. F., and G. A. Broderick. 2006. Effect of varying dietary ratios of alfalfa silage to corn silage on production and nitrogen utilization in lactating dairy cows. J. Dairy Sci. 89:3924-3938.
Broderick, G. A., and M. K. Clayton. 1997. A statistical evaluation of animal and nutritional factors influencing concentrations of milk urea nitrogen. J. Dairy Sci. 80:2964-2971.

Cabrita, A. R. J., R. J. B. Bessa, S. P. Alves, R. J. Dewhurst, and A. J. M. Fonseca. 2007. Effects of dietary protein and starch on intake, milk production, and milk fatty acid profiles of dairy cows fed corn silage-based diets. J. Dairy Sci. 90:1429-1439.

Castillo, A. R., E. Kebreab, D. E. Beever, J. H. Barbi, J. D. Sutton, H. C. Kirby, and J. France. 2001. The effect of energy supplementation on nitrogen utilization in lactating dairy cows fed grass silage diets. J. Anim. Sci. 79:240-246.

Colmenero, J. J. O., and G. A. Broderick. 2006. Effect of dietary crude protein concentration on ruminal nitrogen metabolism in lactating dairy cows. J. Dairy Sci. 89:1694-1703.

Conrad, H. R., A. D. Pratt, and J. W. Hibbs. 1964. Regulation of feed intake in dairy cows. I. Change in importance of physical and physiological factors with increasing digestibility. J. Dairy Sci. 47:54-62

Fellner, V., M. F. Weiss, A. T. Belo, R. L. Belyea, F. A. Martz, and A. H. Orma. 1988. Urine cup for collection of urine from cows. J. Dairy Sci. 71:2250-2255.

Firkins, J. L., M. L. Eastridge, N. R. St.-Pierre, and S. M. Noftsger. 2001. Effects of grain variability and processing on starch utilization by lactating dairy cows. J. Anim. Sci. 79(E. Suppl.):E218-E238.

Holter, J. A., and J. T. Reid. 1959. Relationship between the concentrations of crude protein and apparently digestible protein in forages. J. Anim. Sci. 18:1339-1349.

Ipharraguerre, I. R., and J. H. Clark. 2003. Soyhulls as an alternative feed for lactating dairy cows: A review. J. Dairy Sci. 86:10521073.

Lammers, B. P., D. R. Buckmaster, and A. J. Heinrichs. 1996. A simple method for the analysis of particle sizes of forage and total mixed rations. J. Dairy Sci. 79:922-928.

NRC. 1989. Nutrient Requirements for Dairy Cattle. 6th rev. ed. Natl. Acad. Sci., Washington, DC.

NRC. 2001. Nutrient Requirements of Dairy Cattle. 7th rev. ed. Natl. Acad. Press, Washington, DC.

NRC. 2002. The Scientific Basis for Estimating Air Emissions from Animal Feeding Operations. Natl. Acad. Press, Washington, DC.

Nennich, T. D., J. H. Harrison, L. M. VanWieringen, N. R. St-Pierre, R. L. Kincaid, M. A. Wattiaux, D. L. Davidson, and E. Block. 2006. Prediction and evaluation of urine and urinary nitrogen and mineral excretion from dairy cattle. J. Dairy Sci. 89:353-364.

Oba, M., and M. S. Allen. 1999. Evaluation of the importance of the digestibility of neutral detergent fiber from forage: Effects on dry matter intake and milk yield of dairy cows. J. Dairy Sci. $82: 589-596$.

Onetti, S. G., R. D. Shaver, M. A. McGuire, D. L. Palmquist, and R. R. Grummer. 2002. Effect of supplemental tallow on performance of dairy cows fed diets with different corn silage: Alfalfa silage ratios. J. Dairy Sci. 85:632-641.

Putnam, P. A., and J. K. Loosli. 1959. Effect of feeding different ratios of roughage to concentrate upon milk production and digestibility of the ration. J. Dairy Sci. 42:1070-1078.

Ruppert, L. D., J. K. Drackley, D. R. Bremmer, and J. H. Clark. 2003. Effects of tallow in diets based on corn silage or alfalfa silage on digestion and nutrient use by lactating dairy cows. J. Dairy Sci. $86: 593-609$.

St-Pierre, N. R., and C. S. Thraen. 1999. Animal grouping strategies, sources of variation, and economic factors affecting nutrient balance on dairy farms. J. Anim. Sci. 77(Suppl. 2):72-83.

St-Pierre, N. R., and W. P. Weiss. 2009. Technical note: Designing and analyzing quantitative factorial experiments. J. Dairy Sci. 92:4581-4588.

Tyrrell, H. F., and J. T. Reid. 1965. Prediction of the energy value of cow's milk. J. Dairy Sci. 48:1215-1223.

Valadares Filho, S. C., G. A. Broderick, R. F. D. Valadares, and M. K. Clayton. 2000. Effect of replacing alfalfa silage with high moisture corn on nutrient utilization and milk production. J. Dairy Sci. 83:106-114. 
Voelker, J. A., and M. S. Allen. 2003a. Pelleted beet pulp substituted for high-moisture corn: 1. Effects on feed intake chewing behavior, and milk production of lactating dairy cows. J. Dairy Sci. $86: 3542-3552$.

Voelker, J. A., and M. S. Allen. 2003b. Pelleted beet pulp substituted for high-moisture corn: 2. Effects on digestion and ruminal digestion kinetics in lactating dairy cows. J. Dairy Sci. 86:3553-3561.

Wattiaux, M. A., and K. L. Karg. 2004a. Protein level for alfalfa and corn silage-based diets: I. Lactational response and milk urea nitrogen. J. Dairy Sci. 87:3480-3491.

Wattiaux, M. A., and K. L. Karg. 2004b. Protein level for alfalfa and corn silage-based diets: II. Nitrogen balance and manure characteristics. J. Dairy Sci. 87:3492-3502.
Weiss, W. P., L. B. Willett, N. R. St-Pierre, D. C. Borger, T. R. McKelvey, and D. J. Wyatt. 2009. Varying forage type, metabolizable protein concentration, and carbohydrate source affects manure excretion, manure ammonia, and nitrogen metabolism of dairy cows. J. Dairy Sci. 92:5607-5619.

Weiss, W. P., and D. J. Wyatt. 2000. Effect of oil content and kernel processing of corn silage on digestibility and milk production by dairy cows. J. Dairy Sci. 83:351-358.

Yan, T., J. P. Frost, R. E. Agnew, R. C. Binnie, and C. S. Mayne. 2006. Relationships among manure nitrogen output and dietary and animal factors in lactating dairy cows. J. Dairy Sci. 89:39813991 